\title{
Às voltas com Lévi-Strauss, entrevista com Carlos Fausto
}

Edson Tosta Matarezio Filho

(USP)
Esta entrevista com Carlos Fausto foi realizada em 2012, por ocasião da realização do filme documentário O que Lévi-Strauss deve aos Ameríndios . O nome do filme, inclusive, foi inspirado no título de um artigo escrito a quatro mãos, com Carlos e Marcela Coelho de Souza, chamado "Reconquistando o campo perdido, o que Lévi-Strauss deve aos ameríndios" (2004).

A voz de Carlos destoa da maioria das opiniões mais correntes no Brasil sobre Lévi-Strauss. Por este motivo, suas provocações merecem uma atenção redobrada. O peso da influência da obra do mestre francês na formação de qualquer antropólogo que se aventure no americanismo é notável. Poucos teriam coragem de afirmar que, nos dias de hoje, a obra de Lévi-Strauss, "do ponto de vista de suas proposições teórico-metodológicas, envelheceu, como não poderia deixar de ser".

O entrevistado retoma algumas considerações do texto mencionado acima, principalmente as influências dos Bororo e dos Nambiquara sobre algumas questões que se tornarão clássicas para o estruturalismo. Fausto nos fala sobre os limites da análise estrutural lévi-straussiana e o quanto devemos avançar nos caminhos trilhados por Lévi-Strauss. Em suas pesquisas atuais ele prefere se aventurar no que chama de "pontos cegos" do estruturalismo. Por exemplo, "o ritual é um ponto cego serí́ssimo".

Em tempos em que as etnografias são equiparadas abertamente às mais variadas filosofias, Carlos requisita uma certa ponderação. "Eu acho muito perigoso, isso é uma coisa que me incomoda profundamente, essa atribuição de um determinado pensamento filosófico ao pensamento indígena. Acho isso extremamente pernicioso, porque ele faz supor de alguma maneira que tudo foi pensado dentro da filosofia ocidental". Sua defesa é pela etnografia de longa duração, extremamente minuciosa, principalmente, mas não somente, nos anos iniciais de formação do etnólogo. Antes de alçar grandes voos filosóficos, o etnólogo deve ir "para o mato", começar "a pensar a partir dos dados etnográficos". 
Carlos fala também sobre os indígenas que vêm entrando nas universidades atualmente. Menciona inclusive casos muito próximos a ele, dos Kuikuro, Mutuá [Mehinaku], linguista, e Takumã Kuikuro, cineasta. Sua experiência em formação e capacitação de indígenas é importante para pensarmos os cursos de educação diferenciada que são oferecidos para estas populações.

A trajetória de Carlos Fausto é a de um etnógrafo incansável. Para sua tese de doutorado, o trabalho de campo foi com os Parakanã, o que resultou no livro Inimigos Fiéis: História, Guerra e Xamanismo na Amazônia (2001), leitura obrigatória para os estudiosos dos ameríndios. Atualmente, seu foco etnográfico são os Kuikuro. Em parceria com este povo, dirigiu o longa metragem As Hiper Mulheres, ganhador de diversos prêmios. Seus livros e artigos sobre os povos indígenas perpassam, principalmente, os temas da guerra, do xamanismo, da etno-história, da arqueologia, do ritual e da arte.

Edson Matarezio: Em primeiro lugar, gostaria de saber sua opinião sobre o que muda nos estudos americanistas com a obra do Lévi-Strauss.

Carlos Fausto: O efeito da obra de Lévi-Strauss, para uns, é revolucionário, para outros tem um peso apenas relativo. Eu acho que a primeira coisa que devemos aceitar é que hoje, tantos anos depois, a obra do Lévi-Strauss, do ponto de vista de suas proposições teórico-metodológicas, envelheceu, como não poderia deixar de ser. A partir de meados dos anos 70 você tem uma crítica muito forte a todo o estruturalismo, que foi, num período, hegemônico. A figura de Lévi-Strauss era grande demais, então é natural que você tivesse um processo de saída do estruturalismo, de crítica ao estruturalismo. O que aconteceu nesse processo, no entanto, é que a maioria das pessoas que fizeram a crítica não se deram conta da importância da obra do Lévi-Strauss para a compreensão das populações indígenas das Américas. Essas pessoas leram seus textos programáticos, leram os textos mais clássicos de Antropologia Estrutural e Antropologia Estrutural II, leram O Pensamento Selvagem, O Totemismo Hoje, ficaram no nível das proposições teórico-metodológicas e jamais entenderam a importância que Lévi-Strauss teve na redefinição do campo da etnologia e dos estudos ameríndios. Acho que isso é uma das razões que explica por que, normalmente, quem trabalha com populações indígenas continue lendo Lévi-Strauss com enorme simpatia e abertura ao que ele está dizendo.

Qual a base de Lévi-Strauss para escrever o que escreveu? E estou pensando aqui principalmente, nas Mitológicas, mas não só. Há uma série de trabalhos anteriores, anteriores mesmo a As Estruturas Elementares do Parentesco, que redefiniram, em grande medida, o campo conceitual em que se realizavam os estudos ameríndios. Os textos sobre as organizações dualistas, sobre guerra e comércio, sobre os usos de termos de parentesco na América do Sul, que são da década de 40, antecipavam muito do que ele viria a dizer posteriormente. São contribuições etnográficas, ou melhor, contribuições teóricas mais próximas da etnografia do que as obras que vão ser lidas posteriormente pelos autores que viriam a criticá-lo. Aliás, noto, criticá-lo com toda a legitimidade do mundo de fazer-se a crítica, porque é isso mesmo que a gente deve fazer, a gente não tem que comprar o pacote do que nossos antecessores disseram. Temos que trabalhar com eles de maneira generosa, mas também para 
superá-los, isso faz parte do processo de construção do conhecimento. Agora, há uma sinergia interessante entre Lévi-Strauss e os ameríndios, ainda que ele não tenha tido uma grande experiência de campo, no sentido clássico do nosso trabalho de campo. Lévi-Strauss foi mais um viajante - embora ele diga no início de Tristes Trópicos que odeie as viagens. Ele foi um viajante que passou por algumas populações e foi também um viajante na sua capacidade de leitura do material que então existia. E o que existia era muito pouco. Se você pensar nas Mitológicas, por exemplo, ele constrói aquele universo, principalmente os dois primeiros volumes, a partir de uma literatura que não pode ser qualificada pelo que chamamos hoje de "etnologia moderna". Com exceção dos trabalhos de [Curt] Nimuendaju, que é um fundador da pesquisa de campo aqui, os demais trabalhos eram provenientes de coletas esparsas, de grandes cronistas e de alguns coletores de lendas. Ele parte de um material fonte que não é super sofisticado. E disso ele faz uma enorme obra.

Mas o que acho mais interessante é que os insights de Lévi-Strauss, que estão presentes nas Mitológicas a partir da leitura dessa mitologia, não são apenas sobre o pensamento ameríndio em geral - expressão de que não gosto -, mas de toda uma lógica do sensível, presente não apenas na mitologia. Pois a gente vai encontrar isso em situações práticas, no ritual e assim por diante. Essa sua capacidade de apreender uma lógica subjacente do sensível, eu me deparei com ela quando fui para os Parakanã. Isso foi muito iluminador para mim. Já no início da minha pesquisa de campo, eu me disse: "aquele negócio funciona". A leitura que a gente fazia em abstrato, em sala de aula e que era para nós, nos anos 80 , muito emocionante, tornava-se uma verdadeira descoberta no início de meu campo; percebi que abria um monte de chaves etnográficas para eu trabalhar. A percepção de que aquilo tinha um sentido muito profundo para a compreensão das situações sociais indígenas que eu viria a estudar, teve um impacto muito grande sobre mim. Há um outro impacto também, que é o de um certo estilo de pensamento, estilo de reflexão, uma certa construção do argumento a partir dos dados etnográficos, por meio da formação de uma teia de argumentos a partir de uma série de evidências, em que você começa a trabalhar com as diferenças significativas e com as transformações, que é uma chave para se pensar muito além da mitologia. Isso funcionou para mim como uma disciplina de pensamento, como uma forma de encarar os problemas etnográficos e, a partir deles, construir a análise. Essas são duas coisas que, na minha formação e na minha experiência de leitor de Lévi-Strauss, foram fundamentais, e elas estiveram sempre, para mim, coladas à etnografia. Eu parto sempre da minha experiência etnográfica, embora eu goste de teoria, não gosto muito de produzir modelos dedutivos que se apliquem aos dados, algo que todos imaginam que Lévi-Strauss teria feito. Eu penso, no entanto, que Lévi-Strauss justamente ativa um mecanismo de ligação entre uma indução a partir das propriedades sensíveis presentes numa série de detalhes etnográficos e produz um vai-e-vem com um modelo teórico mais geral. Ele é sempre mais interessante quando faz isso. Portanto, fica muito fácil criticar Lévi-Strauss hoje nos seus elementos mais propositivos e nas limitações que o estruturalismo tinha e tem. É mais complicado, porém, ser generoso e pensá-lo a partir justamente desse movimento que vai da teoria aos dados empíricos. Acho que aí reside ainda a grande graça em continuar lendo Lévi-Strauss e continuar trabalhando com ele. 
EM: Inspirado no artigo que você escreveu com a Marcela Coelho de Souza (2004), gostaria que o senhor falasse sobre a influência dos indígenas sobre a obra de Lévi-Strauss. Dois exemplos importantes são o dualismo dos Bororo e o "minimalismo" social dos Nambiquara. Lévi-Strauss desenvolve bastante estes temas, mas estes povos já possuíam, latentes, ideias que se transformaram em grandes motivos do estruturalismo.

CF: Eu escrevi aquilo há muito tempo com a Marcela, já não me lembro exatamente do argumento nos detalhes. Nos convidaram para escrever aquele artigo, que deveria ter saído nos Cahiers de L'Herne [lzard 2004] em uma edição especial sobre Lévi-Strauss, mas que, por diversas razões, decidimos não publicar lá. A nossa ideia foi, justamente, inverter a pergunta e falar sobre o que Lévi-Strauss devia aos índios. Todo mundo sabe o que ele deve a Jakobson, por exemplo, o que ele deve a Nova lorque, aos surrealistas, mas o que ele deve aos índios? A gente tenta mostrar que ele deve muita coisa. Ele tem uma série de intuições a partir da experiência com os Bororo e com os Nambiquara. Eu chamo de experiência porque não é propriamente uma pesquisa. Você poderia dizer, "bom, mas ele chega, provavelmente, com um modelo filosófico, com problemas filosóficos tipicamente franceses e os projeta sobre essas duas situações empíricas". Eu acho que isso seria desconhecer a grande capacidade que LéviStrauss tinha de leitura dos dados etnográficos. Eu acho brilhante aquela carta do [Curt] Nimuendaju para o [Herbert] Baldus, quando ele pergunta "quem é esse Lévi-Strauss? Quem é esse cara que escreveu sobre o dualismo, sobre os Bororo? " E diz algo como "ele conseguiu em um mês entender um sistema que eu, com anos de pesquisa entre os Timbira, ainda estou lutando para descrever". Então, Lévi-Strauss tinha essa capacidade geométrica de ver, em um só golpe, um sistema em operação e compreender os seus elementos fundamentais. E tem uma elegância na sua descrição. Essa era a nossa ideia. Vamos parar com essa bobagem de criticar Lévi-Strauss como uma pessoa que não fez o trabalho de campo tradicional e vamos entender como ele construiu esse pensamento monumental, teoricamente sutil, rico, em um diálogo que estabeleceu a partir de uma experiência etnográfica precisa. De um lado, há o problema do dualismo, o problema da simetria e da hierarquia, que vai desembocar na ideia dos dualismos concêntrico e diametral com todos os destinos posteriores que isso viria a ter na literatura etnológica. De outro lado, há esse modelo mínimo da sociedade que os Nambiquara lhe ofereceriam, essa espécie de experimento real de um estado natural - para dizer como os contratualistas, daquilo que ele, como leitor de Rousseau, já havia imaginado. E claro que tem toda uma projeção de modelos europeus nisso. Mas acho que, justamente, a genialidade de Lévi-Strauss foi ir além desses modelos em diálogo com essas duas experiências etnográficas. Ele vai construir caminhos, rotas de problemas que vão ser trilhadas por nós, incluindo-me aqui. Claro que há muitas pessoas que me antecedem nisso, mas eu também acabei por trilhar alguns dos seus caminhos. O problema do dualismo vai ser atacado pelos estudiosos dos Jê e vai influenciar muito fortemente o Projeto Harvard Brasil Central, coordenado por [David] Maybury Lewis em cooperação com o Museu Nacional. O modelo nambiquara e o problema da chefia nambiquara, o que hoje chamaríamos de condições mínimas da socialidade, vão ser fundamentais para se pensar uma série de sociedades amazônicas mais minimalistas. Há um outro elemento que perpassa esses dois campos de problemas, que também tentamos explorar, que é aquele do Eu e do Outro, o famoso problema da identidade 
e da diferença, que é uma obsessão francesa. Essa maneira de pensar o problema, que nós hoje chamamos "da alteridade" - e que quase se confunde com nossa etnologia sul-americana - percorre a filosofia francesa durante todo o século XX. Se é um problema francês ou se é um problema ameríndio, eu não posso responder. Alfred Gell, num texto sobre Marilyn Strathern, diz: "eu vou descrever aqui o que vou chamar de Sistema M, pode ser Melanésia ou pode ser Marilyn. Vocês podem escolher". Então, você pode escolher. Do meu ponto de vista, há aqui um desses raros encontros tradutivos.

A ideia, muito romântica aliás, de incomensurabilidade entre esses mundos, ou de um privilégio do pensamento ocidental para pensar esse outro mundo, ou ainda, inversamente, uma espécie de capacidade canibal do mundo ameríndio de deglutir todas as possiblidades existentes, não me parecem funcionar muito bem. Acho que há um encontro tradutivo entre duas possibilidades de ver certos problemas e que permite também evidentemente, permitiu a Lévi-Strauss - ver uma série de coisas e deixar de ver uma série de outras. Foi isso o que nós - Marcela Coelho de Souza e eu - tentamos mostrar, a partir do texto sobre os usos sociais dos termos de parentesco na América do Sul, um texto que abriu todo um caminho para discutir-se a brother-in-lawhood na América indígena; i.e., o lugar da afinidade simétrica, para usar um termo técnico, ou do cunhadio, para empregar um neologismo que a gente cunhou por causa do compadrio. Esse é um idioma fundamental na América do Sul para se falar sobre diferença, mas sobretudo sobre a diferença simétrica. Esse é um tema que venho tentando desenvolver há alguns anos. Por que esse modelo "simetrizou-se" tanto se, no tratamento do dualismo de LéviStrauss, do dualismo concêntrico, a questão da hierarquia estava presente desde o começo? Por que a discussão sobre a diferença e sobre o cunhadio se deu de uma maneira que privilegiou exclusivamente a diferença simétrica? Por que ceifamos todo o problema da diferença colocada de maneira hierárquica? É isso o que eu tenho tentado desenvolver e cujo texto síntese, "Donos Demais" [2008], apresentei em Paris, em 2008, justamente no centenário do Lévi-Strauss e, por isso, dediquei a ele. $\mathrm{O}$ texto começa com uma paráfrase de seu artigo sobre "O uso social dos termos de parentesco entre os índios brasileiros" [Lévi-Strauss 1943]. Em certo sentido, volto ao problema que ele colocou nos primeiros textos sobre o dualismo, em particular sobre o Bororo, mas de uma maneira ampla para a Amazônia como um todo. É curioso porque eu não me definiria como um antropólogo lévi-straussiano, mas continuo pensando e reconhecendo que trilho caminhos que foram abertos por ele e que, de certa maneira, ele antecipou. Felizmente ele não pensou tudo, senão não teríamos mais nada para fazer.

EM: Gostaria de saber sua opinião sobre uma polêmica com relação as possíveis leituras da obra de Lévi-Strauss. Há quem diga que haveria "dois" Lévi-Strauss: um mais preocupado com os universais, outro mais preocupado com os mínimos detalhes do trabalho de campo. Outros dizem que Lévi-Strauss é um só, ele está preocupado com os detalhes, mas para chegar na universalidade do pensamento humano.

CF: Primeiro, creio que um autor não é uma unidade do começo ao fim. Em segundo lugar, cada um se apropria dos autores em função dos seus interesses, das suas predileções. Para mim pouco importa se Lévi-Strauss é um, dois ou dez, eu não acho que isso seja importante - só se você quiser reclamar para si uma herança, mas isso é 
apenas jogo de poder da academia, não um problema intelectual. Acho que nosso problema intelectual é como fazer um bom uso, e o que chamo de bom uso da obra de um autor é você ser generoso com ele. Quer dizer, não querer atribuir a ele mazelas conceituais, teóricas, políticas à toa, mas pensar a partir dele. Você vai pensar a partir daquilo que lhe interessa mais, a não ser, evidentemente, que você esteja fazendo história da antropologia, fazendo uma análise da obra do Lévi-Strauss como autor, à maneira das pessoas que fazem história da filosofia - e mesmo assim nós sabemos que elas não concordam entre si. Então, se não há um Lévi-Strauss, todo mundo pode reclamar seu pedaço da herança. Eu reclamo apenas o fato de que gosto de ler e que tenho uma admiração pela pessoa. Tenho uma admiração por uma série de coisas que ele pensou e ponto. A partir daí é pensar livremente. Há um fato curioso: desde muito cedo, acho que muitos antropólogos brasileiros fizeram isso, a gente enviava os textos para o Lévi-Strauss - esse texto mesmo com Marcela, por exemplo - era uma coisa comum, e ele respondia sempre. Eu tenho as cartas, todas manuscritas, pois ele escrevia com sua caneta tinteiro. E eu me lembro de um artigo que publiquei em 1999 na American Ethnologist, escrevi em 1997 ou 1998, e mandei para ele antes de publicar. Eu fazia lá uma crítica a uma passagem do Minhas palavras [Lévi-Strauss 1986]. Ele respondeu, como sempre, dizendo algo como, "eu não me lembro mais muito bem de tal coisa. Eu não tenho uma memória e tanto. Faz muito tempo". De fato, para ele fazia sempre muito tempo, porque foi muito longevo, mas ele lembrava perfeitamente, porque tinha uma memória impressionante. Ele falou, "bem, eu, quando escrevi isso" - ele fazia uma referência ao canibalismo, ao DNA, enfim toda uma coisa redutora, biologizante - "quando falei isso em um curso do Collège de France, naquela época eu estava empolgado com isso, etc. e tal". Mas não tinha consequência nenhuma. Aí tirei a crítica do meu artigo; pensei: "puxa, que bobagem, estou lendo um pedacinho de uma obra só para pegar no pé do Lévi-Strauss" - não tem coisa mais juvenil. Se você quiser procurar na obra do Lévi-Strauss miuçalhas vai encontrar. Mas voltando a sua pergunta. Lévi-Strauss é um racionalista, cognitivista, deixa muito claro que a antropologia, para ele, é uma ciência menor - isso ele disse explicitamente até o final da vida. Então, é absolutamente legítimo extrair do Lévi-Strauss uma linhagem cognitivista como aquela do [Dan] Sperber. Você também pode fazer do Lévi-Strauss o primeiro pós-estruturalista, como sugere o Eduardo [Viveiros de Castro], um pouco ironicamente talvez, porque isso também nos ajuda a pensar os problemas que nos colocamos agora. Se isso é uma violência ou não com relação a Lévi-Strauss, para mim não é um fato fundamental. No que Lévi-Strauss acreditava, digamos, o núcleo duro daquilo em que ele acreditava é outra coisa. Não há nenhuma dúvida sobre as pretensões universais que ele tinha e frente às quais ele falhou redondamente. Ele sabia disso, por isso acho interessante utilizar seu outro lado, como faz Eduardo. É preciso notar, porém, que há ainda uma outra leitura que se aproxima de Lévi-Strauss por uma aposta cognitivista, mas é diferente daquelas de Dan Sperber ou Pascal Boyer. É uma aposta desenvolvida em grande parte pelo Carlo Severi, a qual também pode ser derivada de Lévi-Strauss e que eu acho muito interessante. O que é importante é você ler de maneira a poder pensar criativamente. Uma das coisas detestáveis na academia é justamente que as pessoas lutam mais por escola, facções, grupos, do que por pensar generosamente os problemas. E uma das coisas boas no mundo intelectual é poder discordar um do outro - não fosse assim, não teria graça nenhuma. 
No entanto, é preciso reconhecer - e isso é relevante - que Lévi-Strauss e o estruturalismo têm uma série de pontos cegos. Como num carro - você está dirigindo e não vê que tinha um outro carro naquele ponto cego. $O$ estruturalismo não é um lugar do qual se pode ver tudo. O pensador estruturalista não é um sujeito solar que vai ver todos os aspectos da realidade. Não, tem pontos cegos. O ritual, por exemplo, é um ponto cego seriíssimo. Eu tentei fazer análises dos rituais parakanã de um ponto de vista bem estruturalista. Evidentemente não fui o primeiro. No nosso contexto quem fez isto foi um aluno do Leach: Stephen Hugh-Jones. Segundo consta, Leach enviou Stephen, Christine Hugh-Jones e [Peter] Silverwood-Cope para a Amazônia com a seguinte incumbência: "vem cá, eu adorei esse negócio de estruturalismo, mas será que isso funciona para escrever uma monografia?". E eles vieram resolver esse problema e fizeram monografias brilhantes, mas também não viram tudo, fizeram uma escolha. Quando fui trabalhar no Xingu, percebi que não dava para continuar dentro desse modelo de análise para pensar o ritual, os artefatos, a assim chamada arte indígena, e comecei a procurar outras possibilidades de análise. Curiosamente, comecei a me aproximar do pragmatismo e do interacionismo, que eram, na nossa formação, os nossos adversários.

EM: Também queria que você comentasse a consideração de Anne-Christine Taylor de que os ameríndios seriam espontaneamente estruturalistas.

CF: Se não me equivoco, Lévi-Strauss fala algo semelhante a esta consideração da Anne-Christine no filme do [Jorge] Bodanzky com Patrick Menget e Jean-Pierre Beaurenaut, A Propósito de Tristes Trópicos [França, 1990, 46']. Ele diz, com uma certa ironia, "eu tenho a impressão de que sempre fui estruturalista e de que os Bororo eram estruturalistas antes de mim". Essa frase não pode ser tomada ao pé da letra. Acho que a consonância se deve a uma série de razões que têm a ver - isso é uma discussão longa - com um tipo de estrutura social e da importância de certos elementos culturais difundidos de maneira ampla na Amazônia, nas Terras Baixas da América do Sul, que são melhor analisados dentro do paradigma estruturalista. Havia uma consonância entre esses dois universos de, vamos dizer, pensamento, embora não ache que o pensamento do Lévi-Strauss possa ser comparado com o pensamento ameríndio (aliás, nem sei se isso existe). Mas havia, de certo, uma consonância que permitia ver coisas que, até então, não se via. O modelo que vinha da experiência inglesa de pesquisa na África e de problemas que eram característicos do pensamento britânico não funcionava para analisar as sociedades indígenas da América do Sul, pelo menos da Amazônia. É claro que você pode imaginar que, se tivesse chegado aqui o Roy Wagner, que tem uma importância fundamental na crítica dos modelos brito-africanos aplicados à Melanésia, ele poderia ter se adaptado maravilhosamente bem, ter trazido outros tipos de questões, iluminado outros aspectos e funcionado brilhantemente. Não é o caso, quem veio foi Lévi-Strauss, e o Lévi-Strauss cumpre esse papel com a sua forma própria de pensamento.

Uma coisa que me incomoda profundamente é a atribuição de um determinado pensamento filosófico ao pensamento indígena. Acho isso pernicioso porque faz supor que, de alguma maneira, tudo foi pensado dentro da filosofia ocidental. Acho de uma arrogância enorme, porque supõe que aquilo que esses caras construíram 
durante séculos, milênios, está contido no interior do pensamento de um autor da filosofia ocidental. Seja ele qual for, pode ser Locke, Hegel, Leibniz, pode ser quem você quiser. Isso para mim é um erro básico e conduz a um problema gravíssimo para o desenvolvimento da etnologia no Brasil: as pessoas não olham mais os dados etnográficos, elas partem desses modelos, os quais são sistemáticos. Sistemas filosóficos são modelos muito pesados. O pensamento ameríndio não pode corresponder ou estar pré-adaptado a eles. Eles são instrumentos, ferramentas e enquanto ferramentas são ótimos. Contudo, quando você passa a supor que existe um negócio chamado pensamento ameríndio e que ele corresponde a alguma coisa que já foi pensada no interior da filosofia ocidental, eu paro, para mim isso não dá! E não acho, justamente, que seja isso o que Lévi-Strauss tenha feito.

É por esta razão que enfatizo esse vai-e-vem entre dados etnográficos e teoria em Lévi-Strauss. Claro que tem uma teoria por trás, tem partidos, tem escolhas, por exemplo, na tetralogia das Mitológicas. É óbvio. Mas como o próprio Lévi-Strauss afirmou, ele passou anos convivendo com aqueles mitos, ele foi contaminado por aqueles mitos - mesmo com seu rigor, com toda sua metodologia - ao fazer a análise daquele material. $\mathrm{O}$ que acontece com Lévi-Strauss nas Mitológicas é que ele é efetivamente, no bom sentido da palavra, contaminado por aquele universo de dados. $E$ isso pôde acontecer sem ele ter ido, estritamente, a campo. Mas exigiu uma leitura enorme, uma familiarização com os dados, uma capacidade muito rigorosa de ler e uma empatia - você tem que estar dentro daquele negócio até que, de repente, aquilo faz sentido para você de uma maneira que nunca tinha feito. Lévi-Strauss fala sobre isso, acho que em De perto e de longe, onde diz "eu acordava e dormia com os mitos na cabeça". É um processo no qual os mitos, em certo sentido, acabam por perpassá-lo, no próprio sentido que ele deu à frase "os mitos falam através das pessoas mais do que as pessoas falam os mitos". Há um artigo da Aparecida Vilaça em que ela se refere justamente a isso. Eu estou aqui apenas reproduzindo o que ela diz de maneira mais precisa e bonita - essa ideia de que a grandiosidade daquilo resulta, de certa maneira, de Lévi-Strauss ter-se deixado atravessar pelos mitos. Os mitos falaram através dele. Evidentemente, não é que não importe a filosofia de Lévi-Strauss. O que ele havia lido, o que não havia lido, claro que importa, porque ele está filtrando tudo isso, mas ele vai além disso. Senão não valeria a pena. Por que você vai ficar dormindo ao relento, fazendo viagens, muitas vezes aventurosas, cheias, como se diz no Rio, de perrengues, para encontrar aquilo que você poderia sentar na biblioteca da sua casa e ler? Essa questão, para mim, é quase militante, porque acho que a antropologia não é projetar modelos e sistemas de pensamento filosófico sobre o universo etnográfico. Sobretudo, ela não pode ser isso. Muitas vezes, quando as pessoas leem trabalhos que têm uma base filosófica muito importante, eles acham que, no início da carreira, é isso que devem fazer. Mas não é isso que se deve fazer no início da carreira. No início da carreira se tem que fazer o que Lévi-Strauss fez, ir para o mato, começar a pensar a partir dos dados etnográficos. Lévi-Strauss não ficou ali muito tempo? Não ficou, mas nós podemos ficar - contudo, talvez não iremos fazer uma obra comparativa desse espectro após dois anos num mesmo lugar. São apostas diferentes, ambas válidas. O que não é possível é imaginar que aquilo que se vai encontrar já está previsto no interior da história da filosofia ocidental. 
EM: O estruturalismo tem os seus limites, mas me parece que Lévi-Strauss tinha uma noção bem clara disso também. O que seria mais importante enfatizarmos seria não esses dados filosóficos mais gerais da obra, mas o outro lado, o lado das especificidades, especialmente as Mitológicas. Lévi-Strauss organizou um material que antes era caótico, definiu os grandes motivos da mitologia ameríndia. A forma original como ele pensou os mitos, como uma sinfonia, como formas de composição da música clássica de um certo período. Talvez seja essa a grande contribuição.

CF: Eu não sou a melhor pessoa para falar sobre a estrutura das Mitológicas, eu sei tanto quanto você. Sou um leitor interessado em estabelecer as pontes entre aquilo que estou lendo, o universo com o qual estou trabalhando, e os problemas que me acompanham. Isso é curioso, eu nunca tive um projeto: "primeiro vou fazer isso, depois vou fazer aquilo", as coisas foram mais ou menos acontecendo. Lá na frente, eu descubro que estava pensando as mesmas questões e que tinha algumas obsessões que me acompanhavam. Sempre que preciso escrever um projeto para pedir dinheiro para alguma coisa, tenho que parar e pensar: "o que eu estou fazendo mesmo?". Aqueles milhões de coisas que estou fazendo, como é que eu junto isso? Porque você tem que vender um peixe chamado "projeto", e todos têm, é inescapável. E é bom que a gente seja obrigado a fazer isso para parar e pensar. Eu poderia dizer um monte de coisas sobre as Mitológicas do ponto de vista de sua pergunta. Mas seriam todas elas de um cara que nunca as leu desse ponto de vista.

Primeiro, como disse, o que sempre me interessou nas Mitológicas foi uma chave de leitura dos mitos. Boa parte, para bem e para mal, da etnologia feita na Amazônia tem como uma das fontes essenciais a mitologia. Todos nós trabalhamos com isso. As Mitológicas oferecem uma chave para pensar um monte de coisas, para estabelecer relações, para fazer uma espécie de ginástica simbólica de alto impacto - e eu sempre funcionei bem nisso. Em segundo lugar, há outra coisa nas Mitológicas que sempre me chamou a atenção: a finura na maneira de trabalhar com os dados do sensível e os organizar em grandes temas - grandes temas que são, digamos assim, de um lado ameríndios, mas também humanos. O tema da mortalidade é um bom exemplo. Uma terceira coisa que sempre me interessou, principalmente a partir do momento em que comecei a conviver mais com a cultura francesa, é o fato de que a tetralogia só poderia ser escrita por um francês. No sentido mais comum do termo, não por um professor do Collège de France, très cultivé, etc., não, do francês comum, que sabe a diferença entre o cru e o cozido, para quem o podre é importante, que come queijos podres - no sentido técnico da palavra - para o qual as maneiras à mesa são fundamentais. Isso faz parte de um universo mental francês. É uma coisa que poucas pessoas notaram, um brasileiro jamais escreveria aquele livro. Não porque não haja um brasileiro suficientemente "cultivé", que tenha lido $X, Y$ e Z, que tenha aprendido literatura clássica, que tenha frequentado museus e coisa do gênero, não!, simplesmente porque nós jamais organizaríamos um livro dessa maneira: o cru e o cozido não são categorias fundamentais para nós. O podre, a gente não come podre! Viemos a comer cru com a comida japonesa, virou uma coisa comum, mas isso não faz parte do nosso universo culinário, então não é sequer pensável. E o triângulo culinário é fundamental na obra do Lévi-Strauss, e também é tanto uma chave tanto gastronômica 
quanto uma chave geral de leitura de um monte de fenômenos ameríndios. Eu poderia dizer que talvez haja uma consonância entre os franceses e os ameríndios, e que os ameríndios - quiçá - eram franceses antes que os franceses aqui chegassem. Essa frase, que parece absurda, é do mesmo nível que a frase anterior: a de que eles eram estruturalistas antes mesmo do estruturalismo chegar.

São esses três elementos que sempre foram para mim a grande atração das Mitológicas. Muito mais do que a estrutura, a semelhança com a música etc. Até porque comecei a trabalhar com música, com etnomusicologia, muito recentemente. A música é um elemento que sempre me escapou, por ignorância, não por ser menos importante. E me escapou por uma falha de formação dos etnólogos, não só no Brasil, como no mundo inteiro. A música interessa mais aos índios do que a nós, não-músicos. Quero dizer, claro, como todos nós, sexo e comida interessam para caramba, mas nunca vi gente tão amante da música quanto os povos com os quais trabalhei. Muito mais, digamos, do que um adolescente que fica em seu quarto, trancado, ouvindo música o dia todo. O fato de que não tenhamos formação musical, não saibamos lidar com isso, é uma falha de formação talvez tão grande quanto aquela de você ir a campo sem nenhuma formação em linguística, tendo que aprender uma língua ágrafa. Hoje eu revejo isso, talvez com minha aproximação maior com a música, que devo à exigência dos Kuikuro e não à minha capacidade. Aliás, isso eu devo aos Kuikuro, entre várias outras coisas. Hoje, se fosse ler as Mitológicas estaria talvez mais atento à estrutura musical da obra.

EM: Gostaria que você comentasse, Carlos, o fato de atualmente termos muitos indígenas entrando na universidade. Inclusive em cursos de pós-graduação, no Brasil todo, cada vez mais, em cursos de antropologia também. Você acha que existe uma nova filosofia por vir desse encontro, mas em outro nível, agora mais dentro da academia, dessa geração que está começando a ter acesso a esse estudo ocidental?

CF: Nos últimos dez anos tenho trabalhado muito com formação e capacitação, no meu caso específico, com os Kuikuro. Mas acompanhei também a experiência da Bruna [Franchetto], no longo tempo em que estivemos casados, quando ela esteve envolvida com experiências de educação bicultural, bilíngue, diferenciada, participando de cursos de formação de professores e das primeiras experiências de universidades indígenas. Acompanhei um pouco esse processo, por vezes de maneira também pessoal porque Mutuá [Mehinako] - que é um mehinakokuikuro - fez o mestrado no Museu Nacional, na área de antropologia linguística, com a Bruna. Eu o conheço desde garoto e tenho uma relação muito próxima, é um grande amigo. Trabalhando com vídeo, tive ainda experiência com Takumã [Kuikuro], que viveu em minha casa durante o ano que cursou a escola Darcy Ribeiro [no Rio de Janeiro] na área de cinema.

A questão que você colocou é relevante: será que esse novo contexto em que as populações indígenas estão ingressando na universidade, seguindo formações diversas, irá conduzir a novas maneiras de pensar, novas maneiras de ver, uma nova antropologia? Eu não sei dizer, muito francamente, porque também pode acontecer que essa diferença, que eles podem trazer, venha a ser engolida por um determinado tipo de sistema. A educação, bem, a gente sabe como funciona, é um dispositivo que conforma muito a maneira das pessoas pensarem, sobretudo se 
elas fizeram uma formação escolar desde crianças. Este não era o caso do Mutuá e do Takumã, que vieram a fazer isso já adultos. Aliás, eles aprenderam português só a partir do final da adolescência. Isso influencia a maneira de pensar. Eu tive conversas ótimas com o Mutuá sobre ciência, feitiçaria, espíritos e tal. Porque a gente tinha que negociar tudo isso, inclusive quando demos um curso juntos sobre o Alto Xingu no PPGAS do Museu Nacional. Se eles têm que estudar, por exemplo, biologia nas universidades e nos cursos de formação, como é que você lida com as duas formas de conhecimento? Eu dizia assim para Mutuá: "biologia é o seguinte..." ou "ciência é o seguinte: você tira os itseke" - que é uma palavra kuikuro para, digamos, "espírito" - "e você vai explicar tudo o que você puder explicar sem botar itseke no meio. Isso é ciência. Você simplesmente tira os itseke da sua explicação; você não pode dizer que foi o espírito que é o dono do pequi, o espírito não-sei-do-que-lá, que causou a doença, você tira isso. Alma também você tira, aí você tenta explicar sem colocar esses elementos como elementos explicadores". A gente tinha muitas dessas conversas. E não é só isso que faz a diferença, tem toda uma discussão sobre o que é o corpo, o que são as relações, que coloca uma série de desafios tradutivos quando os índios começam a andar nesse novo contexto.

Agora, se isso vai produzir alguma coisa nova, de novo, não sei dizer. Esta é uma questão que foi colocada com relação à produção indígena em vídeo, foram inúmeras as discussões. Imaginava-se que, se os índios vão filmar, eles vão filmar de uma maneira diferente, se eles vão fazer a montagem, eles vão montar de uma maneira diferente e vai aparecer uma estética indígena. Na verdade, a maioria dos produtos que nós temos até agora é resultado de uma produção compartilhada, um produto intercultural híbrido. Acho que há uma pegada, uma diferença, que é produzida por uma série de razões e que tem a ver com o mundo indígena, com um modo, sim, de filmar diferente, com uma intimidade particular com o contexto social com o qual se está lidando, com um modo diverso de pensar certas questões. Mas também não vamos exagerar; o pessoal que está filmando vê cinema, vê televisão, vê Rede Globo. O universo de referências não é só o indígena, isso não existe. Imaginar que isso vai gerar uma produção puramente indígena, que vai renovar a estética ou vai renovar a filosofia ocidental, é uma espécie de romantismo primitivista. Acho que pode é ampliar o campo de diálogos e de possibilidades, vai ampliar a conversa humana, como [Clifford] Geertz falava. Isso falta hoje na reflexão sobre a diferença cultural: uma visão um pouco mais humanista, mais generosa. Estamos numa fase de um anti-humanismo simplificado. Voltando a Lévi-Strauss, ao humanismo ampliado do qual ele fala, chegou a hora de pensar o que seria esse humanismo ampliado num mundo contemporâneo. Eu tendo a ver como um processo em que você vai ter uma interfertilização, em que você vai ter diálogos ruins e diálogos bons, com essas pessoas que, hoje, estão se formando dentro do universo escolar da nossa sociedade. Teria que se repensar, aliás, toda a questão da educação diferenciada. Hoje existe uma demanda dos índios ao dizer "não, nós não queremos uma educação diferenciada, porque essa educação diferenciada para nós significa uma subeducação, nós queremos ir para as melhores universidades, estudar com vocês". Está na hora de repensar, de rediscutir e ver onde isso vai dar. Vão ocorrer muitos atritos: atritos sobre autoridade, quem pode representar o quê, quem não pode representar o quê, o que é legítimo representar e assim por diante. Se nós começarmos a achar que determinada pessoa, seja ela um antropólogo indígena ou não indígena, tem prioridade 
para representar um povo, aí nós estamos no mau caminho. Se nós virmos isso como uma possibilidade de ampliar as perspectivas, para pensar generosamente esses outros universos, acho isso maravilhoso, e tenho trabalhado muito nessa direção.

EM: Você mencionou um certo humanismo, que é trazido também com esses povos. Gostaria que você comentasse a relação desse novo humanismo, que Lévi-Strauss já antevia nos anos 60 , esse humanismo ampliado, que inclui o mundo, as coisas, os animais, o ambiente, etc.

CF: Na verdade, é uma questão filosófica muito complexa esta do humanismo e do anti-humanismo. A gente podia tomar, um pouco como Lévi-Strauss o faz a certa altura do "Raça e História" [1976], a ideia de que o mundo indígena é um mundo de humanismo restrito, em que as fronteiras da humanidade acabam nas fronteiras da tribo, como se dizia no passado. Eu acho que a releitura que o Eduardo Viveiros de Castro faz dessa questão dos etnônimos indígenas a partir da sua propriedade pronominal, dêitica, e da ideia da ampliação do humanismo por meio da atribuição da condição humana a animais e coisas, recoloca a discussão num outro patamar. Mas ela não é simples. Quer dizer, de início ela já não é simples do ponto de vista das práticas indígenas. Se é um humanismo ampliado - ampliado por incluir seres não-visíveis, animais, etc. -, ele implica um universo de relações predatórias como esquema fundamental de relação. Mesmo os defensores dos direitos dos animais - e aqui não estou sendo irônico -, os pensadores que procuram expandir as questões da ética e da filosofia moral para abarcar a relação com os animais, o que eu acho absolutamente pertinente e necessário, não vão encontrar ali - a não ser que tentem romantizar o mundo indígena - aquilo que normalmente esperam encontrar. Claro, há maior diálogo entre o xamã e o espírito da anta, mas a anta mesma a gente mata para comer. Então não vamos confundir essas coisas que estão em planos diferentes. Acho, no entanto, que todas essas possiblidades de pensar mundos ontológicos diferentes, nos ajudam a refletir contemporaneamente sobre o que queremos do ponto de vista ético-moral e o que queremos do ponto de vista das relações humanas nesse sentido ampliado. Interessam-me mais as questões colocadas pelas sociedades indígenas do que as respostas que elas dão a essas questões. Essas respostas, justamente, nós temos que construir juntos, negociando. Ninguém aqui tem o privilégio de dar a resposta a esses problemas, serão respostas sempre provisórias, dependem do tempo que a gente está vivendo. As questões relativas à educação, relativas à relação entre antropólogos, indígenas e não-indígenas nos colocam uma série de dilemas difíceis de pensar, porque ainda estão acontecendo. A gente está lidando com eles na prática, mas precisamos torná-los, também, objetos de reflexão. Eu citei o Lévi-Strauss dos três humanismos porque talvez a gente precise de um quarto. Talvez possamos pensar mais uma vez na esteira do Lévi-Strauss, mas pensar daqui para a frente.

Edson Tosta Matarezio Filho é Pós-Doutorando em Ciência Social (Antropologia Social) pela Universidade de São Paulo (USP).

Carlos Fausto é Doutor em Antropologia pela Universidade Federal do Rio de Janeiro (MN/UFRJ) e Professor Associado do Museu Nacional (MN/UFRJ). 
NOTAS

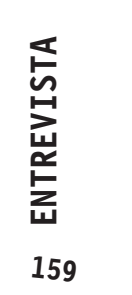




\section{REFERÊNCIAS BIBLIOGRÁFICAS}

FAUSTO, Carlos. 2001. Inimigos Fiéis: História, Guerra e Xamanismo na Amazônia. São Paulo: EDUSP. 2008. “Donos demais: maestria e domínio na Amazônia". Mana 14(2): 329-366.

IZARD, Michel (ed.). 2004. Cahier de l'Herne "Lévi-Strauss" (n82). Paris: Editions de l'Herne.

LÉVI-STRAUSS, Claude. 1943. "The social use of kinship terms among Brazilian Indians". American Anthropologist 45: 398-409.

1976. "Raça e História”. In: Antropologia Estrutural II. Rio de Janeiro: Tempo Brasileiro.

1986. Minhas palavras. São Paulo: Brasiliense.

SOUZA, Marcela Coelho de; FAUSTO, Carlos. 2004. "Reconquistando o campo perdido: o que Lévi-Strauss deve aos ameríndios". Revista de Antropologia 47(1): 87-131. 